\title{
Green Spaces Availability versus Accessibility: Case of Okhla, South Delhi

\author{
Bushra Saba
}

\begin{abstract}
Green spaces are inevitable for people to live and grow. These spaces form an ambit for interaction with nature and people from myriad groups. This paper examines the availability of such spaces in ward no. 102S and 101S of South Delhi and the resident's accessibility to these spaces. The green cover available per person in Sarita Vihar is 14.645 Sq $\mathrm{m} /$ Person which fulfils the URDPFI and WHO guidelines in contrary to $3.969 \mathrm{Sq} \mathrm{m} / \mathrm{Person}$ for Abul fazal enclave. The Public parks are located towards the periphery in Sarita Vihar, more than the walking distance of 400m. 1 public park exists in Abul Fazal Enclave toward the extreme periphery accessible with a ticket of Rs 30 for the adults. It concludes giving possible recommendations at a micro level for better allocation of green spaces based on factors of density and context of the settlement.
\end{abstract}

Keywords: Accessibility, Green infrastructure, Guidelines, Policies.

\section{INTRODUCTION}

The paper attempts to question the basic norms and guidelines set by various National as well as global institutes. As per WHO Norms, Per capita, green space required is $9 \mathrm{sq}$ $\mathrm{M}$ and as per URDPFI guidelines, it is 12-14 sq $\mathrm{M}$. The research question focuses on the provision of accessible green spaces to all and the location of green patches in the city. Does it vary as per the density and context of a place? Does it vary as per the settlement pattern and the distance of such spaces from the CBD as well as last mile connectivity of such areas?

In the Indian context, one such example is AMRUT (Atal Mission for Rejuvenation and Urban Transformation). 500 cities are taken up having a population greater than one lakh. As per this mission, the ULB's need to Develop at least one children park every year in the AMRUT cities. However, there has been no mention about the context, density or the

Table- I: AMRUT Milestones

\begin{tabular}{|c|c|c|c|}
\hline \multirow{2}{*}{ Sl. No } & \multicolumn{3}{|c|}{ AMRUT } \\
\hline & Year & No. of milestone & Maximum score \\
\hline 1. & $1^{\mathrm{st}}$ & 28 & 280 \\
\hline 2. & $2^{\text {nd }}$ & 13 & 130 \\
\hline 3. & $3^{\text {rd }}$ & 10 & 100 \\
\hline 4. & $4^{\text {th }}$ & 3 & 30 \\
\hline
\end{tabular}

Manuscript received on 22 October 2021 | Revised Manuscript received on 03 November 2021 | Manuscript Accepted on 15 November 2021 | Manuscript published on 30 November 2021. * Correspondence Author

Bushra Saba*, Department of Architecture and Regional Planning, IIT Kharagpur, Kharagpur, India. Email: bushrasaba52@gmail.com

(C) The Authors. Published by Lattice Science Publication (LSP). This is an open access article under the CC-BY-NC-ND license (http://creativecommons.org/licenses/by-nc-nd/4.0/)
Table- II: A common milestone for all the milestones by AMRUT

\begin{tabular}{|c|c|c|c|}
\hline $\begin{array}{l}\text { FY-2015-2016 } \\
\text { (28) }\end{array}$ & $\begin{array}{l}\text { FY-2016-2017 } \\
\text { (13) }\end{array}$ & $\begin{array}{l}F Y-2017-2018 \\
(10)\end{array}$ & $\begin{array}{l}F Y \\
2018-2019 \\
\text { (3) }\end{array}$ \\
\hline $\begin{array}{l}\text { Urban Planning } \\
\text { and City } \\
\text { Development } \\
\text { Plans. } \\
\text { Develop at least } \\
\text { one children } \\
\text { park every year } \\
\text { in the AMRUT } \\
\text { cities. }\end{array}$ & $\begin{array}{l}\text { Urban Planning } \\
\text { and City } \\
\text { Development } \\
\text { Plans. } \\
\text { Develop at least } \\
\text { one children } \\
\text { park every year } \\
\text { in the AMRUT } \\
\text { cities. }\end{array}$ & $\begin{array}{l}\text { Develop at least } \\
\text { one children } \\
\text { park every year } \\
\text { in the AMRUT } \\
\text { cities. }\end{array}$ & $\begin{array}{l}\text { Develop at } \\
\text { least one } \\
\text { children } \\
\text { park every } \\
\text { year in the } \\
\text { AMRUT } \\
\text { cities. }\end{array}$ \\
\hline
\end{tabular}

Accessibility of these parks to be developed. The score is given on the basis of proof photograph sent by the ULB's to the Town and Country Planning Organization (Development, 2015). Table I shows the number of milestones to be achieved by the cities yearly and their scoring.

Table II shows the milestone of AMRUT, pointing the development of one Children Park every year in the AMRUT cities as a mandatory step.

\section{LITERATURE STUDY}

\section{A. Submission of the paper}

In a paper, Evaluation of Accessibility to Urban Green Space in Beijing authored by Min Yuan, the accessibility to green spaces have been categorised in two categories. The first one is the actual accessibility; it focuses on the actual use of the space. The second one is the potential accessibility, it emphasises on the availability of green spaces within an area. This research measures the potential accessibility to green spaces. It also focuses on the ways to measure the green space availability in the area. He suggests two ways. The first one is to calculate the amount of green space within a defined region (Potestio et al., 2009; Richardson et al., 2010). The second is to quantify accessibility to these green spaces using Euclidean distance or distances along the road (Comber et al., 2008; Coombes et al., 2010; Kessel et al., 2009) (Yuan, n.d.).

Another paper on Factors Influencing Perceptions and Use of Urban Nature: Surveys of Park Visitors in Delhi authored Somajita Paul and Harini Nagendra suggest ways to study the green spaces. In this paper they have set three objectives. Out of which the first one is to analyse the prime use of the urban parks by people of myriad domains. The second is to assess the variation in the opinion of the people with regard to the value of the natural space and the third is to understand the proximity to the green patches and their connection of those spaces from their dwelling site. It also talks about how frequently a space is being used (Nagendra, 2017).

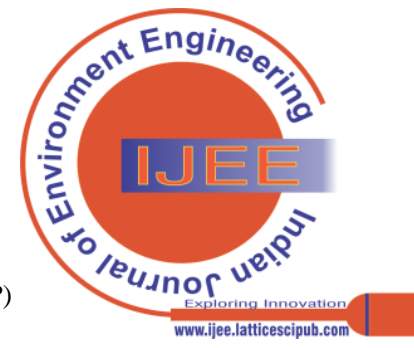


Furthermore, a paper titled, Rethinking Accessibility in Planning of Urban Open Space Using an Integrative Theoretical Framework by Dong Wang, Iderlina Mateo-Babiano and Gregory Brown, has given a conceptual model for park accessibility. The parameters stated werePhysical-transport dimension, Knowledge dimension and Socio-personal dimension. The physical-transport dimension includes number or area of parks, their proximity, the walkability, the car ownership of people, the travel time required for going to the parks and also the travel cost. The Knowledge dimension includes the awareness and the information about the parks to the residents of the area and also the knowledge about the events and functions that occur there. The third dimension, i.e. Socio-personal dimension includes safety of the park users, the shared activities, the ethnic and cultural groups in the neighbourhood, social exclusion if any, the time for leisure by the residents in the nearby. It also considers the lifestyle of the people, their health, the life cycle they have as well as their monetary affordance. (Dong Wang, 2013)

As per a report labelled "Understanding the relevance and application of the Access to Natural Green Space Standard" prepared by Land Use Consultants in 2008 various standards have been set at a micro level. The report has stated various standards such as no person should reside more than $300 \mathrm{~m}$ away from a green space, there should be at least one 20ha accessible green space within $2 \mathrm{~km}$ from the place of residence, there should be at least 1 ha of statutory local nature reserve (LNR) per 1000 population and various other micro level standards have been put forward in the report (Consultants, 2008).

\section{INFERENCES FROM LITERATURE STUDY}

The users of green space are generalized without considering the differences in needs, preference, and behavior among population groups. Green space accessibility for different age, ethnic, income and occupation groups should be assessed separately in future studies. Factors determining the attractiveness of individual green space are more complex. Thus more indicators to describe green space should be included. Accessibility is based on walking distance. Other travel modes such as private vehicle, biking, and public transit are necessary in order to provide a complete understanding of green space access. Rather than the only "built-up" class for clustering population, which actually has merged buildings, roads and hard-pave public spaces, more classes such as high intensity and low intensity should be obtained in the future studies.

\section{CASE STUDIES}

\section{A. Chicago, Illinois}

If you are using Word, use either the Microsoft Equation Editor or the MathType add-on (http://www.mathtype.com)

For equations in your paper (Insert | Object | Create New Microsoft Equation or MathType Equation). "Float over text" should not be selected.

Green Roof Programs: Chicago has various programmes through which it gives incentives to people who build green roofs for their buildings. The incentives are provided from Green Roof Improvement Fund and Green
Roof Grant Program. In three years this programme offered grants to 72 projects with the fund. An amount of $\$ 5000$ was given in 2005, 2006 and 2007. (Wetlands, 2010)

Green Alley Program: In 2006, an eminent measure was taken by the Chicago Department Of Transportation (CDOT) to reduce flood. The department identified 3500 acres of alleys having impervious pavement. To increase the infiltration of runoff, several tests were done with different types of materials. Finally in 2009, the CDOT had carried out the programme in hundred plus alleys. The programme became permanent towards the dawn of 2009. (Wetlands, 2010)

Green Permit Program: The program works with a view of providing a lower permit fee for those who qualify for green built. This incentive is provided by the Department of Buildings Green Permit Program. (Wetlands, 2010)

\section{B. Portland, Oregon}

The properties that have an impervious surface of more than 500 sq $\mathrm{ft}$ need to follow the Pollution reduction and flow control requirements set by Portland. The projects aiming at discharging new storm water outlets outside their site also have to comply with the above mentioned requirements. (Wetlands, 2010)

\section{Santa Monica, California}

The Government gives a landscape grant of $\$ 160,000$ annually to the people who use landscaping ways that lead to lesser consumption of water and acts as a good runoff absorbent. (Wetlands, 2010)

\section{INTRODUCTION TO THE STUDY AREA}

Okhla is located in the South Delhi district of National Capital Territory of Delhi. The newly planned settlement NOIDA (New Okhla Industrial Development Area) has bought the name from the native name of Okhla. Okhla is the assembly constituency and its number is 54 . There are 5 wards within this constituency. They include Zakir nagar (ward no: 100S), Sarita Vihar (ward no: 101S), Abul Fazal enclave (ward no: 102S), Madanpur Khadar East (ward no: 103S) and Madanpur Khadar West (ward no: 104S).

\section{A. Location}

Map1 shows the location of South Delhi district in New Delhi. The wards chosen for study are ward no $102 \mathrm{~S}$ and 101S. They lie adjacent to each other and are separated by narrow nalah. Map2 below shows the location of the wards in Okhla Assembly constituency.

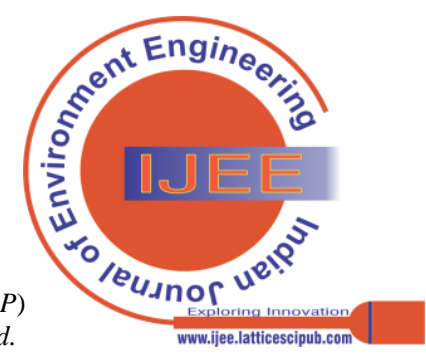




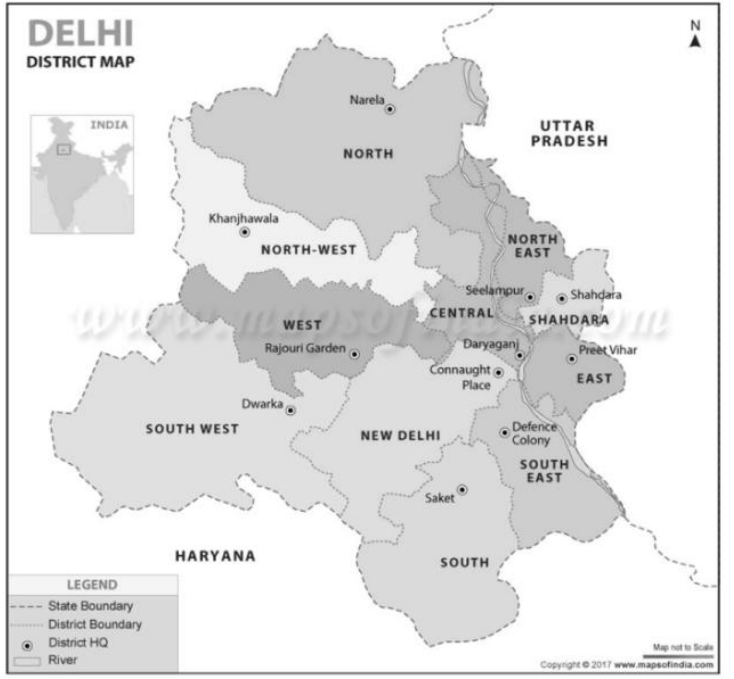

Map 1. Location of South Delhi district in New Delhi.

Abul fazal enclave lies towards the east of Okhla Assembly constituency and Sarita Vihar lies towards the west in Okhla.

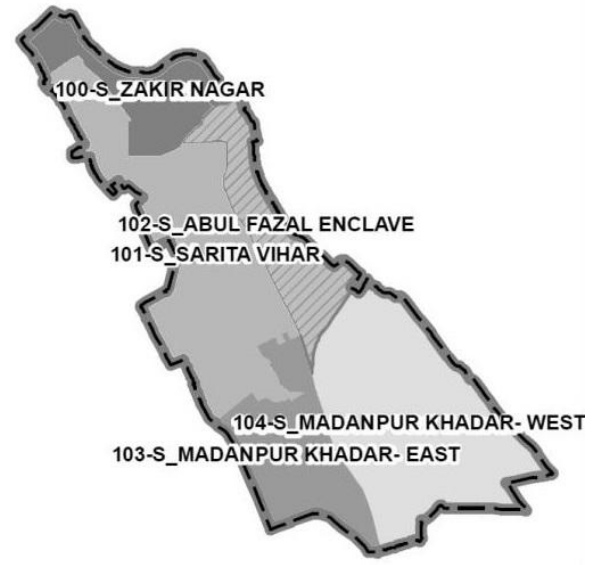

Map 2. Wards as seen within Okhla constituency

\section{WARDS DESCRIPTION}

\section{A. Sarita Vihar (101S)}

Sarita Vihar has a total area of $4.71 \mathrm{Sq} \mathrm{Km}$ with a population of 70,124 . The population density of the ward is 14,888 persons per Sq Km. it has a total built up of 1.188 $\mathrm{SqKm}$ and total green cover of $1.027 \mathrm{Sq} \mathrm{Km}$. The area of green cover to the total area of the ward is 0.218 . i.e $21.8 \%$ of available to the total built-up area in the site, it is $0.864 \mathrm{Sq} \mathrm{Km}$ i.e. $86.4 \%$ of the total built-up area on the site. Moreover, green cover available per person in Sarita Vihar is $14.645 \mathrm{Sq}$ $\mathrm{m} /$ Person. It fulfils the URDPFI guidelines, that states that green cover should be $14 \mathrm{Sq} \mathrm{m} /$ Person and also WHO guidelines that states that the green cover should be $9 \mathrm{sq}$ $\mathrm{m} /$ person.

\section{B. Abul Fazal Enclave (102S)}

Abul fazal enclave has a total area of $2.07 \mathrm{Sq} \mathrm{Km}$ with a population of 68,271 . The population density of the ward is 32,981 persons per Sq Km. it has a total built up of 0.874 $\mathrm{SqKm}$ and total green cover of $0.271 \mathrm{Sq} \mathrm{Km}$. The area of green cover to the total area of the ward is 0.130 , i.e. $13 \%$ of the total area of the ward. If we quantify the green spaces available to the total built-up area in the site, it is 0.310, i.e. the total area of the ward. If we quantify the green spaces

$31 \%$ of the total built-up area on the site. Moreover, green cover available per person in Abul fazal enclave is $3.969 \mathrm{Sq}$ $\mathrm{m} /$ Person. It does not fulfil the URDPFI guidelines, that states that green cover should be $14 \mathrm{Sq} \mathrm{m} /$ Person and also WHO guidelines that states that the green cover should be 9 sq $\mathrm{m} /$ person.

\section{COMPARATIVE ANALYSIS}

The table shows a comparative analysis of both the wards in Okhla assembly constituency. SaritaVihar ward has aample green space availability and fulfils all the standards of various organisations. However, Abul Fazal ward that lies in the immediate adjacent location does not have the required green space at all.

Graph no4 shows that maximum people (48\%) visited the gardens at Jamia Millia Islamia university campus, that lies out of the ward in which they stay. $28 \%$ visited parks at other locations. $15 \%$ visited the parks at Kalindi kunj, that lies in the ward. 5\% people visited Tikona park that also do not lie within the ward and also not at a walking distance. 5\% people visited Canal colony park that also do not lie within the ward but is at a walking distance for the residents of Abul Fazal enclave.

Table- III: Comparison of the Wards

\begin{tabular}{|c|c|c|}
\hline Ward name and No. & $\begin{array}{c}\text { Sarita vihar } \\
\text { (101S) }\end{array}$ & $\begin{array}{c}\text { Abul fazal } \\
\text { enclave (102S) }\end{array}$ \\
\hline Total Area & $4.71 \mathrm{Sq} \mathrm{Km}$ & $2.07 \mathrm{Sq}$ km \\
\hline Total population & 70,124 & 68,271 \\
\hline $\begin{array}{l}\text { Population Density } \\
\text { (P/SqKm) }\end{array}$ & 14,888 & 32,981 \\
\hline $\begin{array}{l}\text { Total built up } \\
\text { (SqKm) }\end{array}$ & 1.188 & 0.874 \\
\hline $\begin{array}{l}\text { Total green cover } \\
\text { (SqKm) }\end{array}$ & 1.027 & 0.271 \\
\hline $\begin{array}{l}\text { Green cover/ Total } \\
\text { area }(\mathrm{SqKm})\end{array}$ & 0.218 (21.8\%) & $0.130(13 \%)$ \\
\hline $\begin{array}{l}\text { Green cover/ Built } \\
\text { area (SqKm) }\end{array}$ & $0.864(86.4 \%)$ & $0.310(31 \%)$ \\
\hline $\begin{array}{l}\text { Green cover/Person } \\
\text { (URDPFI: } 14 \\
\text { sqm/Person)(WHO: } \\
9 \text { sqm/person) }\end{array}$ & $\begin{array}{l}\text { 14.645 Sq } \\
\text { m/Person }\end{array}$ & $\begin{array}{l}3.969 \mathrm{Sq} \\
\mathrm{m} / \text { Person }\end{array}$ \\
\hline $\begin{array}{l}\text { Public parks } \\
\text { (No, Area covered in } \\
400 \mathrm{~m} \text { buffer) }\end{array}$ & 5, $1.5 \mathrm{SqKm}$ & $1,0.25 \mathrm{SqKm}$ \\
\hline $\begin{array}{l}\text { Private parks } \\
\text { (No, Area covered in } \\
400 \mathrm{~m} \text { buffer) }\end{array}$ & 6,2.51 SqKm & 0,0 \\
\hline
\end{tabular}

\section{PRIMARY SURVEY}

Primary survey was conducted in Kalindi Kunj park at Abul Fazal enclave ward. It was found that $70 \%$ of the people visited parks and only $30 \%$ did not go to the parks. Only $42 \%$ people said that the park was located in their locality. However, 58\% people responded by saying that there was no park in their locality. Graph 1 and graph 2 below show the results

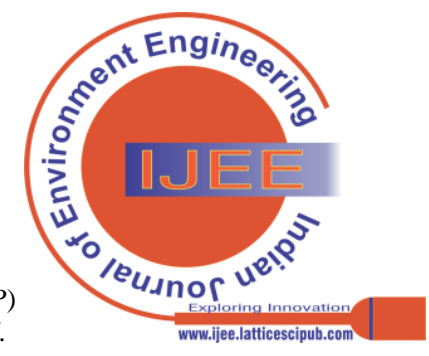




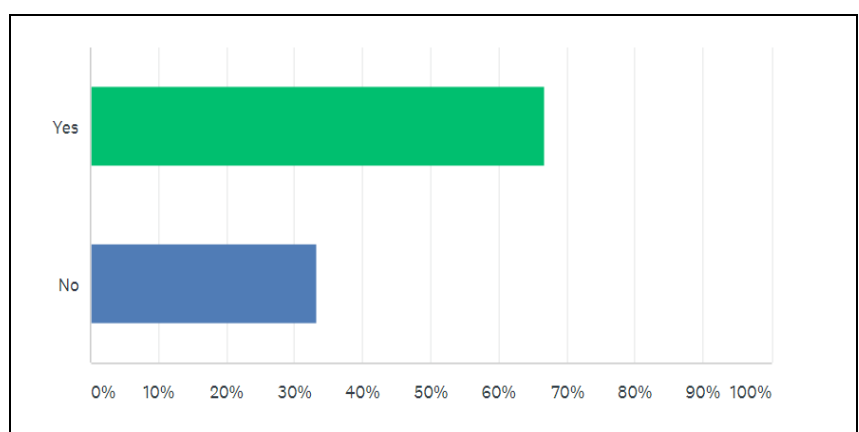

Graph 1: Percentage of people visiting a park

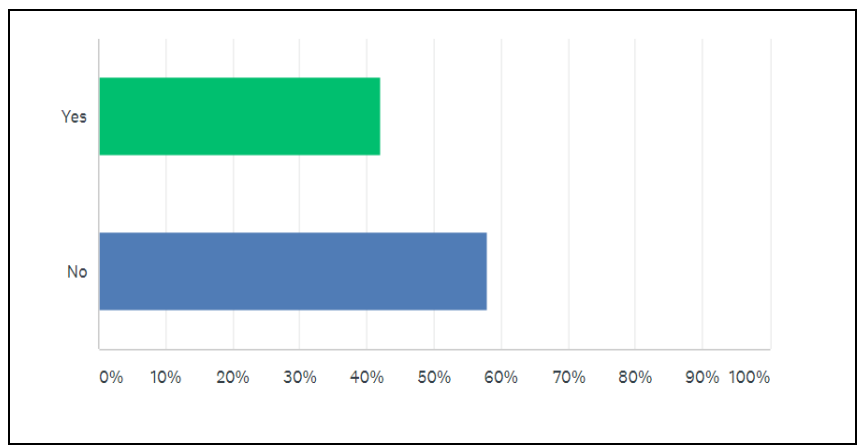

Graph 2: If yes, is the park in the residential locality?

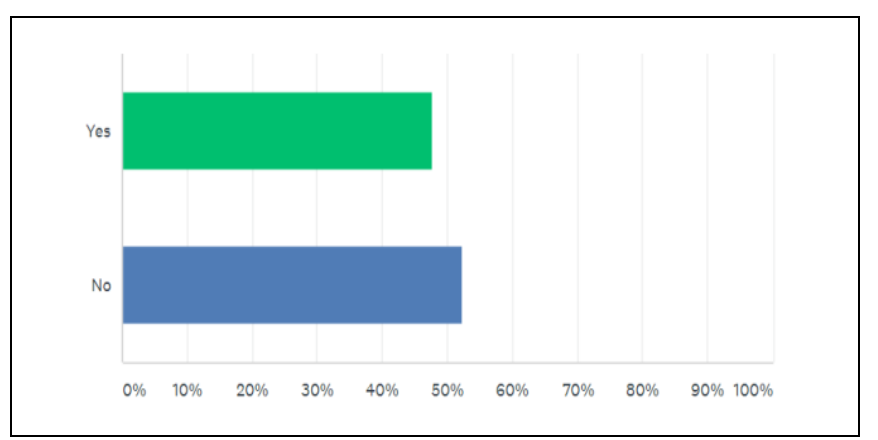

Graph 3: Is the park at a walking distance from home?

Graph no 3 shows that $52 \%$ people state that the parks are located at walking distance from their home. However, $48 \%$ said that it was far off and could not go their walking.

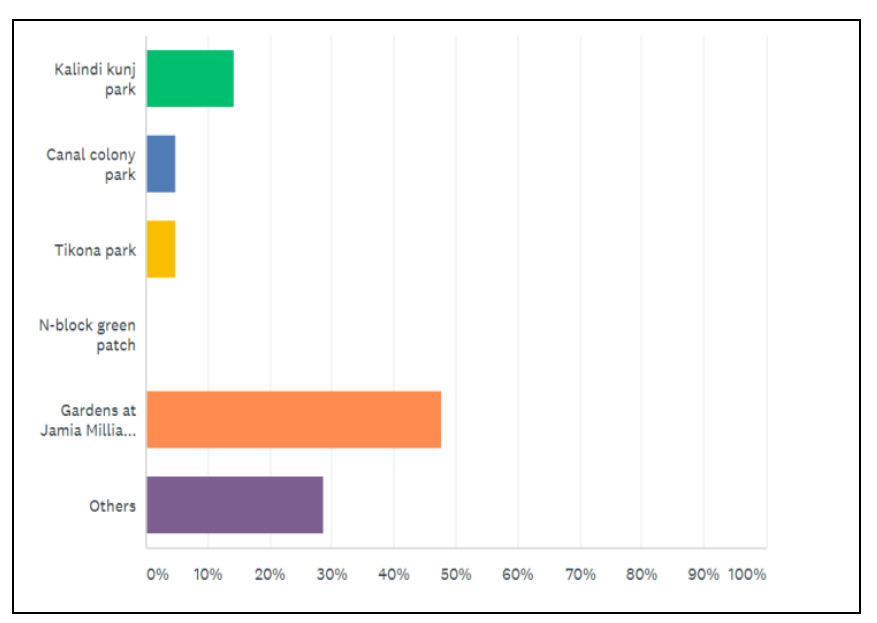

Graph 4: Percentage of people visiting various parks

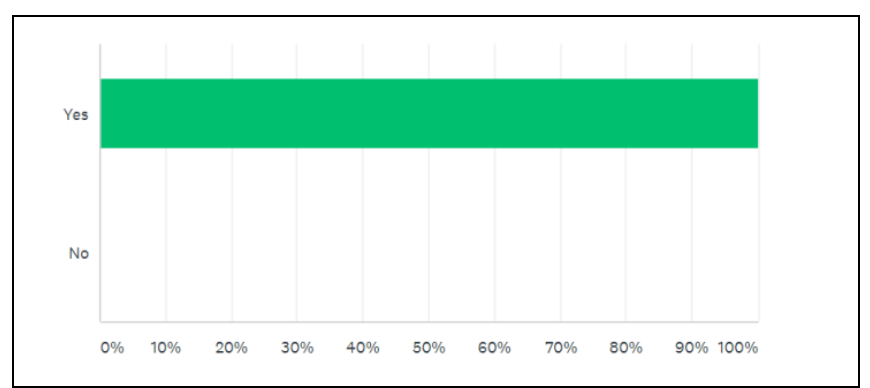

Graph 5: Should there be a park set up by corporation/authority in the ward?

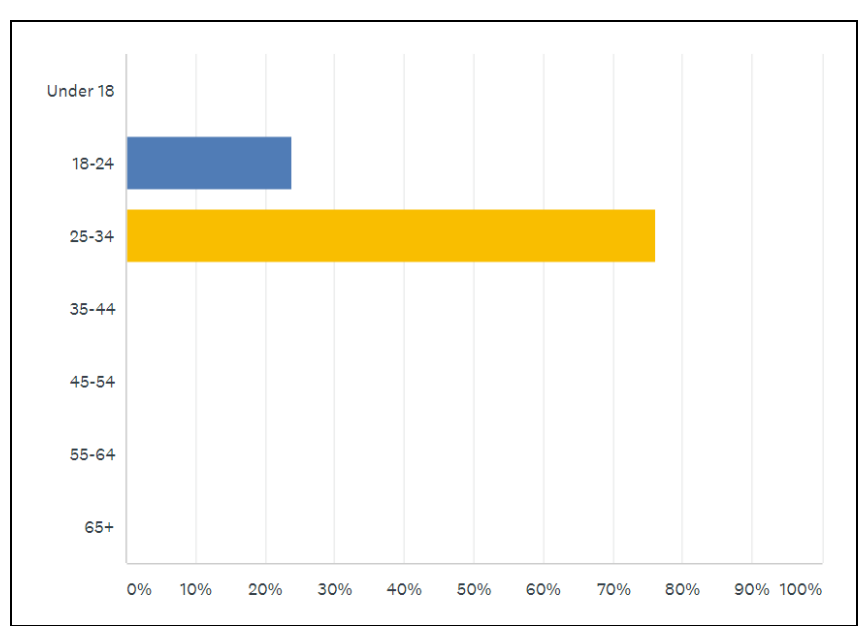

Graph 6: Age group of people going to the parks

The maximum people going to the park belonged to the age group of 25 to 34 . It counted to $77 \%$ of the people. $23 \%$ people belonged to an age group of 18 to 24 . The park visitors were mainly of young age group as they have to travel to go to the parks and are not at a walking distance. Graph No.5 shows that $100 \%$ want a park to be set up by the Government in the ward. This reflects the dire need for such an initiative that should be taken.

Map No.3 shows the built-up and green spaces in Abul fazal enclave and Sarita vihar ward. It can be seen that Abul Fazal enclave has a dense built-up structure (shown in black in the map) in comparison to Sarita vihar (shown in brown in the map). Graph No.7 shows the percentage of green cover in both the wards. It is observed that Abul Fazal Enclave has only $13 \%$ of the total area as green cover and is not evenly located in the ward. However, in Sarita Vihar 22\% is green cover and is almost evenly located within the ward.

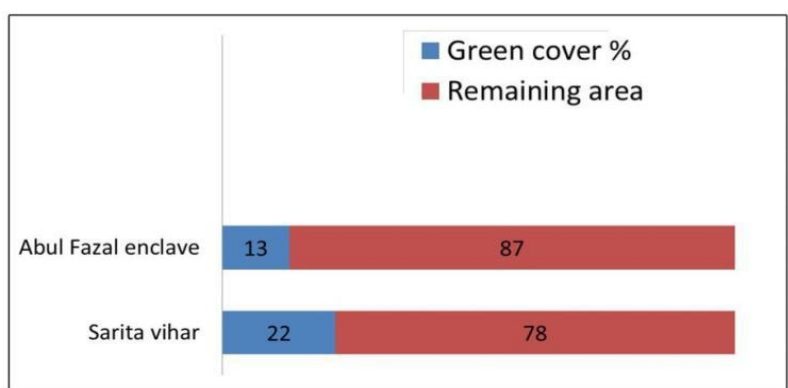

Graph 7: Green cover in the wards

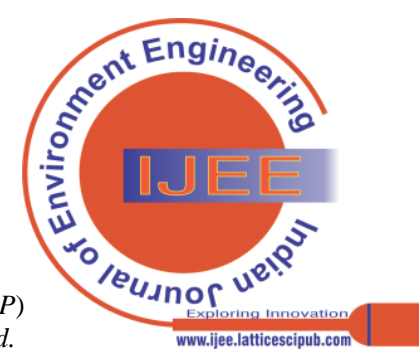




\section{GREEN COVER ANALYSIS}

In Sarita Vihar even though the green space availability standard is fulfilled, the spaces are not accessible by all. Private parks are located within the built up pockets. Map No.4 shows that public parks are located towards the periphery in Sarita Vihar, more than the walking distance of $400 \mathrm{~m}$. However, in Abul Fazal Enclave only 1 Public park exists toward the extreme periphery. That too is set up by the
Uttar Pradesh government and a ticket of Rs 30 is charged for the entry of the adults. Figure1, below shows the charges for various activities within Kalindi Kunj park located in Abul Fazal Enclave ward. Thus, daily accessibility as well as affordability remains a challenge for the residents of the ward. There are other open spaces and green patches that are private owned. However, the mere availability of a green patch remains a prime concern in such areas.

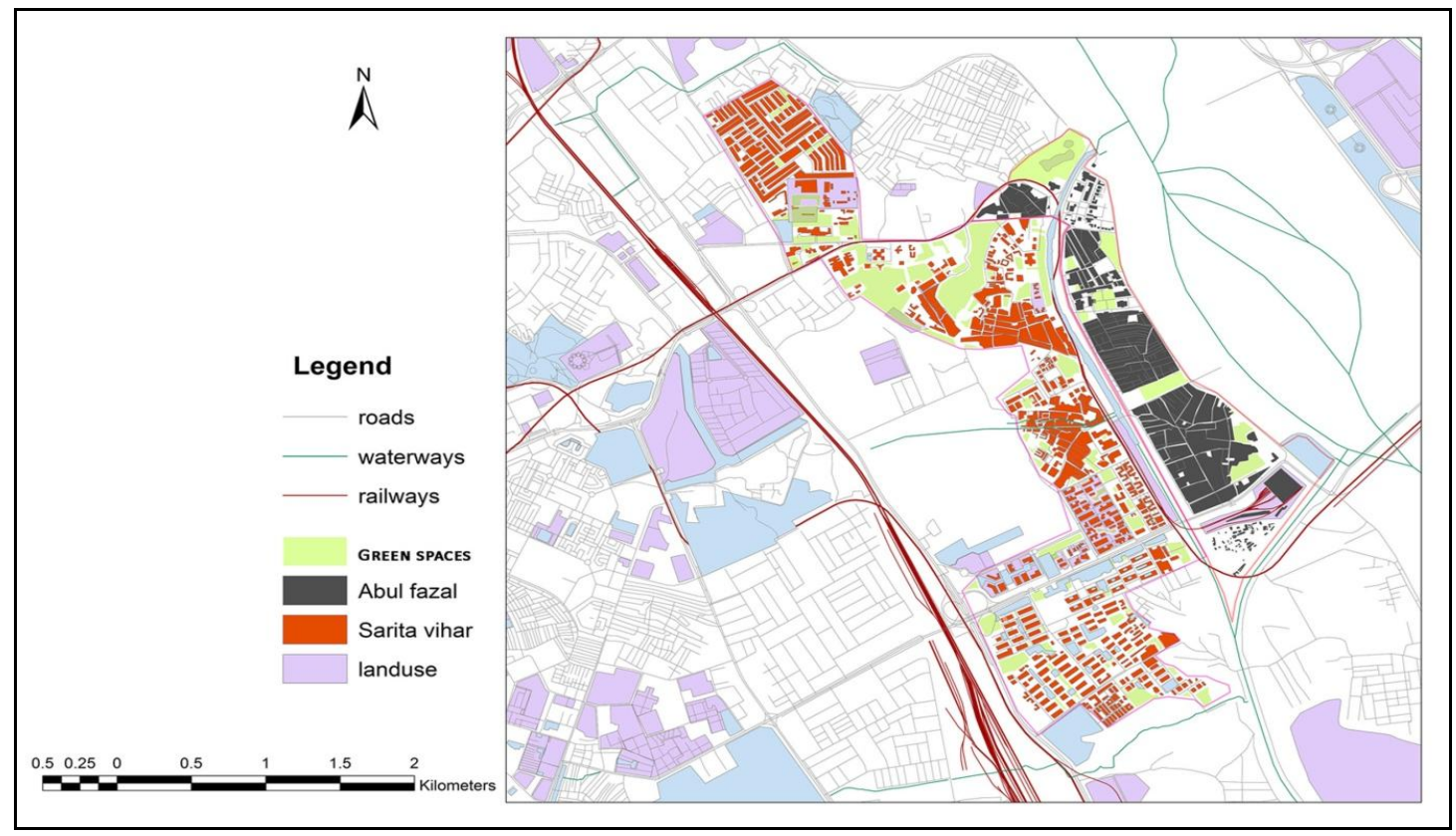

Map 3. Built spaces in the wards

The map shows the built-up and green spaces in Abul Fazal enclave and Sarita Vihar ward. It is observed that Abul Fazal enclave has a dense built-up structure (shown in black in the map) in comparison to Sarita Vihar ward. (2021)

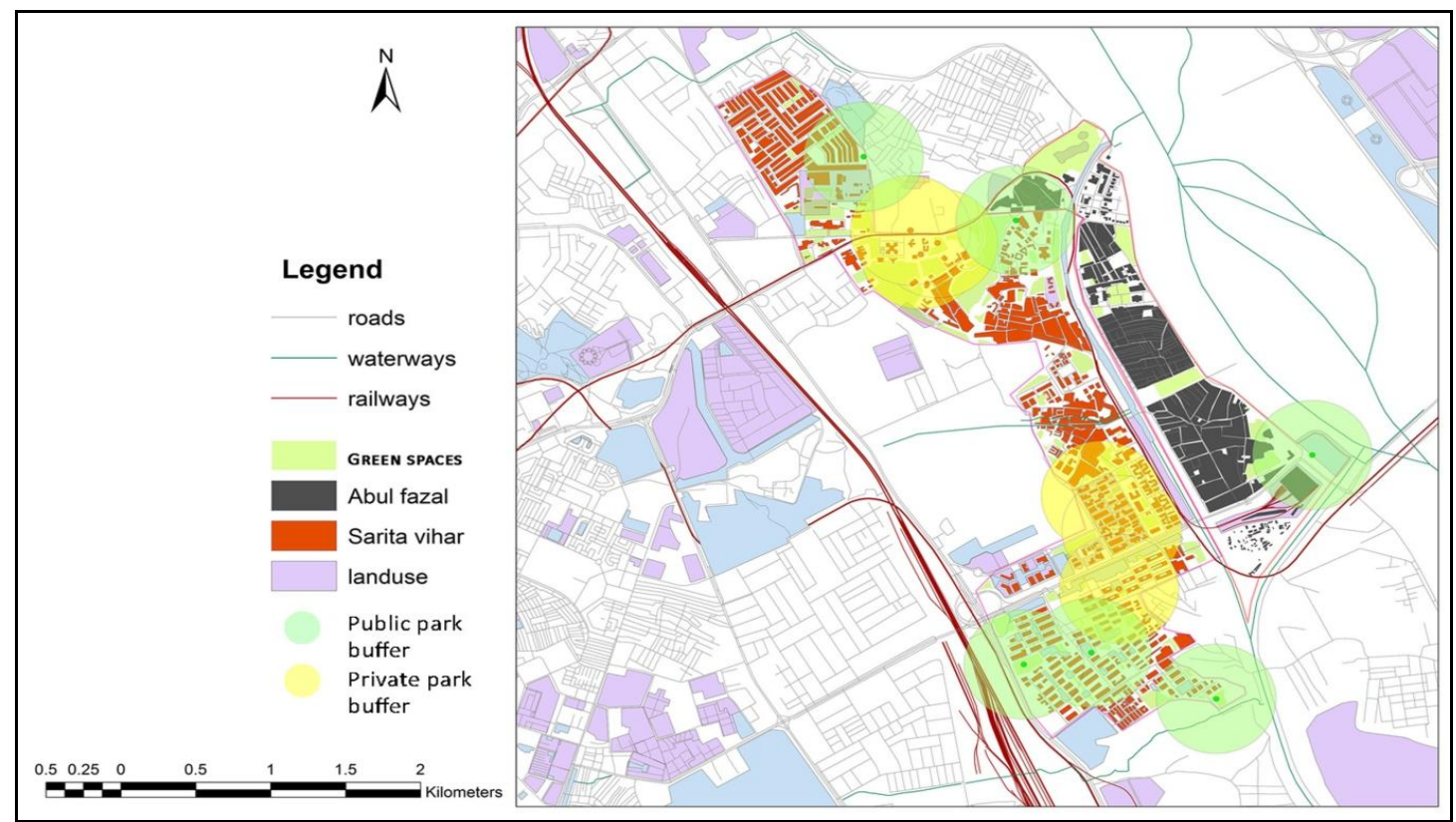

Map 4. Location of parks and buffer in the wards

The map shows the location of Public parks towards the periphery in Sarita Vihar, more than the walking distance of $400 \mathrm{~m}$.

However, in Abul Fazal Enclave only 1 Public park exists toward the outskirts of the ward and is of a paid type. (2021)

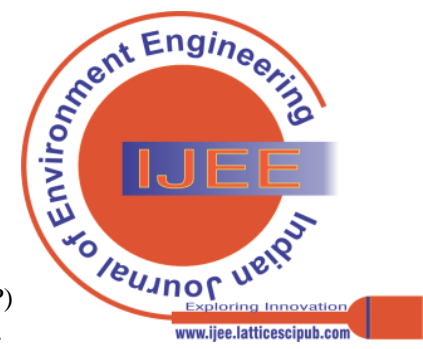




\section{CONCLUSION}

In order to provide for the green spaces in a dense packed settlement area, the spaces in the public institutions could be made available to the public at off times. In Sarita vihar, public parks are available but they are confined to the periphery of the ward. Towards the center are the private parks and the public parks are not at a walking distance for the residents of the ward.

Primary survey conducted during the study revealed that people want such spaces to be developed by the Government. It also showed that access these spaces, but due to the unavailability it only remains a desire for few people and those who can travel, either go to the green spaces in the institutes or somewhere far off. As the parks fail to cater to all age groups due to their location, it also leads to certain groups being excluded. The sustainable Development Goal 11 talks about leaving no one behind, and that should be kept in mind while allocating such spaces. Thus, proper accessibility as well as availability remains of a prime concern. Even the availability of such spaces at a larger distance hinders the usage by senior citizens as well as children. The other factors that need to be considered are the provision of green spaces for multi-functional use of space that can be adopted at various other places. Lately, the Indian Government has been emphasizing on the provision of Children Park in the

\section{REFERENCES}

1. Consultants, L. U., 2008. Understanding the relevance and application of the Access to Natural Green Space Standard, London: Natural England.

2. Development, M. o. U., 2015. Atal Mission for Rejuvenation and Urban Transformation, New Delhi: Government of India.

3. Dong Wang, I. M.-B. a. G. B., 2013. Rethinking Accessibility in Planning of Urban Open Space Using an Integrative Theoretical Framework. State of Australian Cities Conference, p. 11.

4. Nagendra, S. P. a. H., 2017. Factors Influencing Perceptions and Use of Urban Nature: Surveys of Park Visitors in Delhi. Land, April, p. 23.

5. Yuan, M., n.d. Evaluation of Accessibility to Urban Green Space in Beijing, s.l.: Quantitative Method in Environmental Planning

\section{AUTHORS PROFILE}

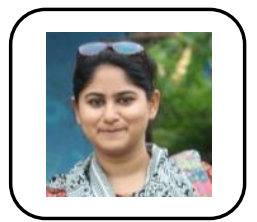

Bushra Saba, is a PhD scholar at IIT Kharagpur with bachelor's degree in Architecture from Jamia Millia Islamia University and Master's degree in Urban and Regional Planning from School of Planning and Architecture. She is a recipient of best thesis awards from Institute of Town Planners, India (ITPI), Delhi Urban Art Commission (DUAC)

design awards, C.P. kukreja Design Awards and Rajya Puraskar.

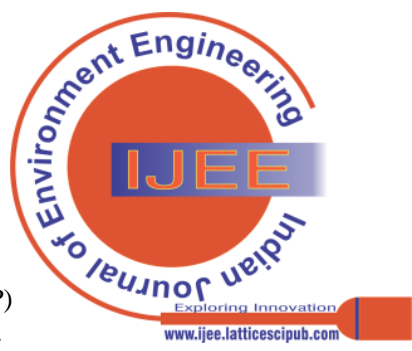

